\title{
Arthropods of Steel Creek, Buffalo National River, Arkansas. III. Heteroptera (Insecta: Hemiptera)
}

\author{
Michael Joseph Skvarla ${ }^{\ddagger}$, Danielle M. Fisher ${ }^{\ddagger}$, Ashley P.G. Dowling ${ }^{\ddagger}$
}

‡ University of Arkansas, Fayetteville, United States of America

Corresponding author: Michael Joseph Skvarla (mskvarla36@gmail.com)

Academic editor: Laurence Livermore

Received: 23 Dec 2015 | Accepted: 11 May 2016 | Published: 16 May 2016

Citation: Skvarla M, Fisher D, Dowling A (2016) Arthropods of Steel Creek, Buffalo National River, Arkansas. III. Heteroptera (Insecta: Hemiptera). Biodiversity Data Journal 4: e7607. doi: 10.3897/BDJ.4.e7607

\begin{abstract}
Background

This is the third in a series of papers detailing the terrestrial arthropods collected during an intensive survey of a site near Steel Creek campground along the Buffalo National River in Arkansas. The survey was conducted over a period of eight and a half months using twelve trap types - Malaise traps, canopy traps (upper and lower collector), Lindgren multifunnel traps (black, green, and purple), pan traps (blue, purple, red, white, and yellow), and pitfall traps - and Berlese-Tullgren extraction of leaf litter.
\end{abstract}

\section{New information}

We provide collection records for 54 species of Heteroptera, 11 of which were new state records for Arkansas: (Aradidae) Aradus approximatus, Aradus duzeei, Aradus ornatus, Neuroctenus elongatus, Neuroctenus pseudonymus, Notapictinus aurivilli; (Cydnidae) Sehirus cinctus; (Lygaeidae) Nysius raphanus; (Miridae) Prepops insitivus; (Reduviidae) Zelus tetracanthus; (Rhyparochromidae) Kolenetrus plenus. 


\section{Keywords}

Heteroptera,Alydidae, Aradidae, Coreidae, Cydnidae, Gerridae, Lygaeidae, Miridae, Pachygronthidae, Pentatomidae, Reduviidae, Rhyparochromidae, Scutelleridae, Thyrecoridae, Tingidae, state record, range expansion, Interior Highlands, Boston Mountains

\section{Introduction}

The Ozarks are a biodiversity hotspot that has been relatively understudied compared to similar areas, such as the Southern Appalachians (Skvarla et al. 2015). This is the third in a series of papers that detail the arthropod fauna collected during a nine month survey conducted in the Boston Mountain subsection of the Ozarks near the Buffalo National River in northwest Arkansas and highlight species newly recorded from the state (for select Coleoptera see Skvarla et al. 2015 and for "Symphyta" see Skvarla et al. 2016). The geologic and biogeographic history of the region and collection methodology of the study were covered in detail by Skvarla et al. 2015 .

Recent efforts (e.g., Lee and Barton 1983, Allen and Carlton 1989, Chordas et al. 2005, Chordas and Kremers 2008, Kerzhner and Henry 2008, Scudder 2008, Chordas and Kremers 2009, Taylor and Gill 2009, Henry et al. 2010, Chordas et al. 2011, Swanson 2011, Gaspar et al. 2015) have highlighted the true bug fauna of Arkansas. This paper adds to that effort by reporting 11 new species records of Heteroptera from the state.

\section{Sampling methods}

Sampling description: The sampling protocol was covered in detail by Skvarla et al. 2015). The following summary is provided for convienience.

The following traps were maintained within the site: five Malaise traps, twenty-five pan traps, fifteen Lindgren multi-funnel traps, four SLAM (Sea, Land, and Air Malaise) traps, and seventeen pitfall trap sets. Additionally, ten leaf litter samples were collected for Berlese extraction when traps were serviced.

All traps were set by 13 March 2013, except Lindgren funnels, which were set on 1 April 2013. Traps set earlier than 13 March were reset on that date in order to standardize trap catch between traps. Traps were serviced approximately every two weeks (14 \pm 3 days). The last collection of pitfall traps and pan traps occurred on 6 November 2013; Malaise, SLAM, and Lindgren funnel traps were run until 4 December 2013. In total, 1311 samples were collected.

Propylene glycol (in the form of Peak RV \& Marine Antifreeze) was used as the preservative in all traps as it is non-toxic and generally preserves specimens well (Skvarla 
et al. 2014). Insect escape was impeded by the addition of unscented, hypoallergenic detergent to the propylene glycol to act as a surfactant. Trap catch was sieved in the field and stored in Whirl-Pak bags in $90 \%$ ethanol until sorting.

Quality control: Samples were coarse-sorted to easily identifiable levels (generally family, occasionally order or genus) using a Leica MZ16 stereomicroscope illuminated with a Leica KL1500 LCD light source and a Wild M38 stereomicroscope illuminated with an Applied Scientific Devices Corp. Eco-light 20 fiber optic light source. After sorting, specimens were stored in $2 \mathrm{~mL}$ microtubes in $70 \%$ ethanol.

Specimens were identified with the use of published keys (Table 1). Crasswell 2014) was consulted when the authors were unfamiliar with Heteroptera-specific morphological terms.

Table 1.

Species collected, including total number of specimens. New state records are indicated by an an asterisk $\left(^{*}\right)$.

\begin{tabular}{|c|c|c|c|c|}
\hline Family & Genus & Species & $\begin{array}{l}\text { To tal } \\
\text { specimens } \\
\text { collected }\end{array}$ & Identification reference/method \\
\hline Alydidae & Alydus & Alydus eurinus & 2 & $\begin{array}{l}\text { Schaefer } 2004 \text { (to genus); one of } \\
\text { three Alydus in eastern North } \\
\text { America, compared to specimens } \\
\text { in UAAM (to species) }\end{array}$ \\
\hline Alydidae & Megalotomus & $\begin{array}{l}\text { Megalotomus } \\
\text { quinquespinosus }\end{array}$ & 45 & $\begin{array}{l}\text { Schaefer } 2004 \text { (to genus); only } \\
\text { Megalotomus in eastern North } \\
\text { America }\end{array}$ \\
\hline Aradidae & Aradus & Aradus acutus & 7 & $\begin{array}{l}\text { Parshley 1921, Blatchley } 1926 \text {, } \\
\text { Usinger and Matsuda 1959, } \\
\text { Taylor and Gill 2009) }\end{array}$ \\
\hline Aradidae & Aradus & $\begin{array}{l}\text { Aradus } \\
\text { approximatus }\end{array}$ & 1 & $\begin{array}{l}\text { Parshley } 1921 \text {, Blatchley } 1926, \\
\text { Usinger and Matsuda 1959, } \\
\text { Taylor and Gill 2009) }\end{array}$ \\
\hline Aradidae & Aradus & Aradus crenatus & 21 & $\begin{array}{l}\text { Parshley 1921, Blatchley 1926, } \\
\text { Usinger and Matsuda 1959, } \\
\text { Taylor and Gill } 2009\end{array}$ \\
\hline Aradidae & Aradus & Aradus duzeei* & 71 & $\begin{array}{l}\text { Parshley 1921, Blatchley 1926, } \\
\text { Usinger and Matsuda 1959, } \\
\text { Taylor and Gill } 2009\end{array}$ \\
\hline Aradidae & Aradus & Aradus ornatus* & 3 & $\begin{array}{l}\text { Parshley 1921, Blatchley } 1926 \text {, } \\
\text { Usinger and Matsuda 1959, } \\
\text { Taylor and Gill 2009) }\end{array}$ \\
\hline
\end{tabular}




\begin{tabular}{|c|c|c|c|c|}
\hline Aradidae & Aradus & Aradus similis & 2 & $\begin{array}{l}\text { Parshley 1921, Blatchley } 1926 \text {, } \\
\text { Usinger and Matsuda } 1959\end{array}$ \\
\hline Aradidae & Mezira & Mezira sayi & 8 & $\begin{array}{l}\text { Blatchley 1926, Usinger 1936, } \\
\text { Usinger and Matsuda 1959, } \\
\text { Kormilev 1982b, Davidová- } \\
\text { Vilímová et al. 1996, Taylor and } \\
\text { Gill 2009) }\end{array}$ \\
\hline Aradidae & Neuroctenus & $\begin{array}{l}\text { Neuroctenus } \\
\text { elongatus }\end{array}$ & 25 & $\begin{array}{l}\text { Blatchley 1926, Usinger and } \\
\text { Matsuda 1959, Kormilev 1982a) }\end{array}$ \\
\hline Aradidae & Neuroctenus & $\begin{array}{l}\text { Neuroctenus } \\
\text { pseudonymus* }\end{array}$ & 2 & $\begin{array}{l}\text { Usinger and Matsuda 1959, } \\
\text { Blatchley 1926, Kormilev 1982a, } \\
\text { Taylor and Gill } 2009\end{array}$ \\
\hline Aradidae & Notapictinus & $\begin{array}{l}\text { Notapictinus aurivilli } \\
\text { * }\end{array}$ & 1 & $\begin{array}{l}\text { Blatchley 1926, Usinger and } \\
\text { Matsuda 1959, Taylor and Gill } \\
\text { 2009) }\end{array}$ \\
\hline Coreidae & Acanthocephala & $\begin{array}{l}\text { Acanthocephala } \\
\text { terminalis }\end{array}$ & 14 & $\begin{array}{l}\text { distinctive, only species of } \\
\text { Acanthocephala in Arkansas with } \\
\text { brown antenna and contrasting } \\
\text { orange terminal segment, no key } \\
\text { necessary }\end{array}$ \\
\hline Coreidae & Leptoglossus & $\begin{array}{l}\text { Leptoglossus } \\
\text { oppositus }\end{array}$ & 10 & Baranowski and Slater 1986 \\
\hline Cydnidae & Amnestus & $\begin{array}{l}\text { Amnestus } \\
\text { basidentatus }\end{array}$ & 1 & McPherson 1982 \\
\hline Cydnidae & Melanaethus & $\begin{array}{l}\text { Melanaethus } \\
\text { subpunctatus }\end{array}$ & 2 & McPherson 1982 \\
\hline Cydnidae & Pangaeus & Pangaeus bilineatus & 82 & McPherson 1982 \\
\hline Cydnidae & Sehirus & Sehirus cinctus* & 1 & McPherson 1982 \\
\hline Gerridae & Gerris & Gerris argenticollis & 1 & Kittle 1980) \\
\hline Gerridae & Gerris & Gerris marginatus & 2 & Kittle 1980 \\
\hline Lygaeidae & Nysius & Nysius raphanus* & 7 & Slater and Baranowski 1990 \\
\hline Miridae & Prepops & Prepops insitivus* & 1 & $\begin{array}{l}\text { distinctive species, no key } \\
\text { necessary }\end{array}$ \\
\hline Pachygronthidae & Oedancala & Oedancala dorsalis & 9 & Slater and Baranowski 1990) \\
\hline Pachygronthidae & Phlegyas & $\begin{array}{l}\text { Phlegyas } \\
\text { abbreviatus }\end{array}$ & 124 & Slater and Baranowski 1990 \\
\hline Pentatomidae & Banasa & Banasa euchlora & 1 & McPherson 1982 \\
\hline
\end{tabular}




\begin{tabular}{|c|c|c|c|c|}
\hline Pentatomidae & Brochymena & $\begin{array}{l}\text { Brochymena } \\
\text { arborea }\end{array}$ & 15 & McPherson 1982 \\
\hline Pentatomidae & Chinavia & Chinavia hilaris & 7 & McPherson 1982 \\
\hline Pentatomidae & Euschistus & Euschistus servus & 4 & McPherson 1982 \\
\hline Pentatomidae & Euschistus & $\begin{array}{l}\text { Euschistus } \\
\text { tristigmus }\end{array}$ & 4 & McPherson 1982 \\
\hline Pentatomidae & Hymenarcys & $\begin{array}{l}\text { Hymenarcys } \\
\text { nervosa }\end{array}$ & 3 & McPherson 1982 \\
\hline Pentatomidae & Menecles & Menecles insertus & 22 & McPherson 1982 \\
\hline Pentatomidae & Mormidea & Mormidea lugens & 11 & McPherson 1982 \\
\hline Pentatomidae & Podisus & $\begin{array}{l}\text { Podisus } \\
\text { maculiventris }\end{array}$ & 6 & McPherson 1982 \\
\hline Reduviidae & Arilus & Arilus cristatus & 1 & $\begin{array}{l}\text { distinctive species, no key } \\
\text { necessary }\end{array}$ \\
\hline Reduviidae & Barce & & 8 & not identified to species \\
\hline Reduviidae & Melanolestes & $\begin{array}{l}\text { Melanolestes } \\
\text { picipes }\end{array}$ & 4 & $\begin{array}{l}\text { distinctive species, no key } \\
\text { necessary }\end{array}$ \\
\hline Reduviidae & Oncocephalus & $\begin{array}{l}\text { Oncocephalus } \\
\text { geniculatus }\end{array}$ & 12 & Capriles 1995 \\
\hline Reduviidae & Pselliopus & Pselliopus barberi & 43 & Blatchley 1926 \\
\hline Reduviidae & Rhiginia & Rhiginia cruciata & 1 & $\begin{array}{l}\text { distinctive species, no key } \\
\text { necessary }\end{array}$ \\
\hline Reduviidae & Rocconota & $\begin{array}{l}\text { Rocconota } \\
\text { annulicornis }\end{array}$ & 2 & $\begin{array}{l}\text { a single species of Rocconota } \\
\text { occurs north of Mexico }\end{array}$ \\
\hline Reduviidae & Sinea & Sinea diadema & 1 & Caudell 1901 \\
\hline Reduviidae & Sinea & Sinea spinipes & 5 & Caudell 1901 \\
\hline Reduviidae & Stenopoda & $\begin{array}{l}\text { Stenopoda } \\
\text { spinulosa }\end{array}$ & 2 & $\begin{array}{l}\text { Blinn } 2012 \text { (to genus); single } \\
\text { species of Stenopoda north of } \\
\text { Mexico }\end{array}$ \\
\hline Reduviidae & Zelus & Zelus tetracanthus* & 1 & Hart 1986 \\
\hline Rhyparochromidae & Antillocoris & Antillocoris pilosulus & 1 & Slater and Baranowski 1990 \\
\hline Rhyparochromidae & Cryphula & $\begin{array}{l}\text { Cryphula } \\
\text { trimaculata }\end{array}$ & 15 & Slater and Baranowski 1990 \\
\hline
\end{tabular}




\begin{tabular}{|c|c|c|c|c|}
\hline Rhyparochromidae & Kolenetrus & Kolenetrus plenus* & 3 & $\begin{array}{l}\text { Slater and Baranowski 1978; a } \\
\text { single species of Kolenetrus } \\
\text { occurs north of Mexico }\end{array}$ \\
\hline Rhyparochromidae & Myodocha & Myodocha serripes & 1 & $\begin{array}{l}\text { distinctive species, no key } \\
\text { necessary }\end{array}$ \\
\hline Rhyparochromidae & Ozophora & Ozophora picturata & 15 & Slater and Baranowski 1990 \\
\hline Rhyparochromidae & Xestocoris & Xestocoris nitens & 1 & O'Donnell 2007 \\
\hline Scutelleridae & Stethaulax & $\begin{array}{l}\text { Stethaulax } \\
\text { marmorata }\end{array}$ & 4 & McPherson 1982) \\
\hline Thyreocoridae & Corimelaena & $\begin{array}{l}\text { Corimelaena } \\
\text { pulicaria }\end{array}$ & 3 & McPherson 1982 \\
\hline Thyreocoridae & Galgupha & $\begin{array}{l}\text { Galgupha } \\
\text { loboprostethia }\end{array}$ & 4 & McPherson 1982 \\
\hline Tingidae & Acalypta & Acalypta susana & 33 & $\begin{array}{l}\text { Drake and Lattin 1963, Allen et al. } \\
\text { 1988) }\end{array}$ \\
\hline
\end{tabular}

\section{Geographic coverage}

Description: The survey was conducted in 4 hectare plot established at Steel Creek along the Buffalo National River in Newton County, Arkansas, centered at approximately N $36^{\circ}$ 02.269', W 93²0.434'. For additional details, see Skvarla et al. 2015

Coordinates: 36.0367 and 36.0397 Latitude; -93.3917 and -93.3397 Longitude.

\section{Usage rights}

Use license: Creative Commons CCZero

\section{Data resources}

Data package title: Steel Creek survey

Number of data sets: 1

Data set name: Steel Creek Heteroptera

Download URL: http://dx.doi.org/10.5061/dryad.b3f33

Data format: Darwin Core Archive 


\begin{tabular}{|c|c|}
\hline Column label & Column description \\
\hline typeStatus & Nomenclatural type applied to the record \\
\hline catalogNumber & Unique within-project and within-lab number applied to the record \\
\hline recordedBy & Who recorded the record information \\
\hline individualCount & The number of specimens contained within the record \\
\hline lifeStage & Life stage of the specimens contained within the record \\
\hline kingdom & Kingdom name \\
\hline phylum & Phylum name \\
\hline class & Class name \\
\hline order & Order name \\
\hline family & Family name \\
\hline genus & Genus name \\
\hline specificEpithet & Specific epithet \\
\hline scientificNameAuthorship & Name of the author of the lowest taxon rank included in the record \\
\hline scientificName & Complete scientific name including author and year \\
\hline taxonRank & Lowest taxonomic rank of the record \\
\hline country & Country in which the record was collected \\
\hline countryCode & Two-letter country code \\
\hline stateProvince & State in which the record was collected \\
\hline county & County in which the record was collected \\
\hline municipality & Closest municipality to where the record was collected \\
\hline locality & Description of the specific locality where the record was collected \\
\hline verbatimElevation & Average elevation of the field site in meters \\
\hline verbatimCoordinates & Approximate center point coordinates of the field site in GPS coordinates \\
\hline verbatiumLatitude & Approximate center point latitude of the field site in GPS coordinates \\
\hline verbatimLongitude & Approximate center point longitude of the field site in GPS coordinates \\
\hline decimalLatitude & Approximate center point latitude of the field site in decimal degrees \\
\hline decimalLongitude & Approximate center point longitude of the field site in decimal degrees \\
\hline georeferenceProtocol & Protocol by which the coordinates were taken \\
\hline identifiedBy & Who identified the record \\
\hline eventDate & Date or date range the record was collected \\
\hline
\end{tabular}




\begin{tabular}{|l|l|}
\hline habitat & Description of the habitat \\
\hline language & Two-letter abbreviation of the language in which the data and labels are recorded \\
\hline institutionCode & Name of the institution where the specimens are deposited \\
\hline basisofRecord & The specific nature of the record \\
\hline
\end{tabular}

\section{Additional information}

\section{Analysis}

We collected and identified 672 specimens representing 54 species and 43 genera during this study (Table 1).

Eleven species (20\%) represent new state records: (Aradidae) Aradus approximatus, Aradus duzeei, Aradus ornatus, Neuroctenus elongatus, Neuroctenus pseudonymus, Notapictinus aurivilli; (Cydnidae) Sehirus cinctus; (Lygaeidae) Nysius raphanus; (Miridae) Prepops insitivus; (Reduviidae) Zelus tetracanthus; (Rhyparochromidae) Kolenetrus plenus.

\section{Notes on selected species}

Unless otherwise noted, distribution information was assembled from Kittle 1980, McPherson 1982, Lee and Barton 1983, Henry and Froeschner 1988, Taylor and McPherson 1989, Chordas et al. 2005, Chordas and Kremers 2009, Taylor and Gill 2009, Swanson 2011).

Aradus approximatus (Aradidae) is known from Quebec south to Georgia and west to Indiana and Mississippi (Froeschner 1988a). The specimens reported here represent a western range extension.

Aradus duzeei (Aradidae) is known from Quebec and Ontario south to Virginia and west to Missouri (Froeschner 1988a).

Aradus ornatus (Aradidae) is known from New York and Pennsylvania, south to Georgia, and west to Indiana (Froeschner 1988a). Taylor and Gill 2009 recently reported the species from Louisiana.

Neuroctenus elongatus (Aradidae) is known from Pennsylvania, North Carolina, the District of Columbia, Ohio, and Indiana (Froeschner 1988a).

Neuroctenus pseudonymus (Aradidae) is known from the District of Columbia, North Carolina, Tennessee, Ohio, Indiana, Texas, and Louisiana (Froeschner 1988a, Taylor and Gill 2009). 
Notapictinus aurivilli (Aradidae) is known from Florida, Georgia, and Louisiana (Froeschner 1988a, Taylor and Gill 2009). The specimens reported here represent a northern range extension and the first inland records away from Gulf Coastal states.

Sehirus cinctus (Cydinidae) is widespread in North America and occurs from Newfoundland and Quebec south to Florida, west to California and south into Mexico (Froeschner 1988b). It has been previously recorded from all states surrounding Arkansas and its occurrence in the state is unsurprising.

Nysius raphanus (Lygaeidae) is widespread, being found in North America from Ontario, south to Florida, west to British Columbia, California, and New Mexico; it is also known from Mexico and the West Indies (Ashlock and Slater 1988). It has been previously recorded from Missouri, Kansas, and Texas and its occurrence in Arkansas is unsurprising.

Preopos insitivus (Miridae) is widespread in eastern North America, from New Hampshire and Ontario south to Florida, and west to Colorado; it has previously been reported from Missouri (Henry and Wheeler 1988).

Zelus tetracanthus (Reduviidae) is widespread in North America and occurs south through Mexico to Paraguay. It has been previously reported from Missouri, Kansas, and Louisiana (Sibley 1951, Swanson 2011).

Kolenetrus plenus (Rhyparochromidae) is found in cool, xeric fields transcontinentaly in northern North America from Quebec and Massachusetts west to British Columbia and Yukon; disjunct populations occur in mountainous areas in North Carolina, Montana, Arizona, Mexico, and Guatemala (Slater and Baranowski 1978, Ashlock and Slater 1988, Scudder 1993, Maw et al. 2000). The specimens reported here likely represent a disjunct population that is restricted to the Ozarks or Interior Highlands.

Xestocoris nitens (Rhyparochromidae) is known from Quebec, Nova Scotia, and Ontario south to Virginia, west to Michigan, Missouri, and Nebraska (Ashlock and Slater 1988, O'Donnell 2007). Scudder 2010 was the first to record it from Arkansas (Logan County). An unpublished specimen of $X$. nitens, collected in Hempstead County on 5 February 1954 is housed in the University of Arkansas Arthropod Museum and a second unpublished Xestocoris from Pulaski County, which is likely $X$. nitens, is housed in Texas A\&M University Insect Collection (Quinn 2015).

Acalypta susanae (Tingidae) is known from two specimens collected from Mt. Magazine in Arkansas (Allen et al. 1988). The specimens reported here extend the species range northwest into the Boston Mountains and increase the number of specimens in collections. Nymphs, which are undescribed for this species, were collected, although a formal description of immature lifestages is beyond the scope of this work. 


\section{Discussion}

The relative abundance of Acalypta susanae (33 specimens) collected in this study, when compared to the number of previously known specimens (2), is striking. The species is obviously more widespread than previously thought, but it is unclear without additional sampling effort whether it is locally abundant and the sampled site was particularly good habitat or if they are abundant throughtout their range. As the species is a rather distinctive tingid and easily identified, future leaf litter studies in the Interior Highlands and surrounding area should be observent for additional specimens.

Kolenetrus plenus is an interesting species becuase the it has an apparently disjunct range and is restricted to cool, xeric fields in mountainous areas. The specimens reported here are not totally unexpected as the Interior Highlands is the only mountainous region that occurs between the eastern populations in North Carolina and western and southern populations in Arizona and Mexico.

Most of the species newly recorded from Arkansas are widespread in eastern North America and many are known from states that border Arkansas. While their presence in the state is therefore unsurprising, the fact that have have not been previously recorded highlights how under surveyed the state is, especially compared with other biodiversity hotspots.

\section{Author contributions}

Michael Skvarla performed all responsibilities associated with collecting the specimens, including trap maintenance and sample collection; sorted samples; and prepared the manuscript. Danielle Fisher sorted samples and coarse-sorted specimens to higher taxa (order/family). Ashley Dowling supervised the lab in which Skvarla and Fisher performed the work, provided financial support by securing funding, and commented on the manuscript prior to submission.

\section{References}

- $\quad$ Allen RT, Carlton CE (1989) New records of Ceratocombidae and Schizopteridae from Arkansas (Heteroptera: Dipsocoromorpha). Journal of the Kansas Entomological Society 62 (1): 125-126.

- $\quad$ Allen RT, Carlton CE, Tedder SA (1988) A new species of Acalypta (Hemiptera, Tingidae) from Arkansas. Journal of the Kansas Entomological Society 61 (1): 126-130.

- $\quad$ Ashlock PD, Slater A (1988) Lygaeidae. In: Henry TJ, Froeschner RC (Eds) Catalog of the Heteroptera, or true bugs, of Canada and the continental United States. E.J. Brill, New York, 958 pp.

- $\quad$ Baranowski RM, Slater JA (1986) Coreidae of Florida. Florida Department of Agriculture and Consumer Services, Gainesville, Florida, 82 pp. URL: http://ufdc.ufl.edu/ UF00000092/00001 [ISBN 0066-8036] 
- Blatchley WS (1926) Heteroptera or true bugs of Eastern North America with especial reference to the faunas of Indiana and Florida. The Nature Publishing Company, Indianapolis, 1116 pp. DOI: 10.5962/bhl.title.6871

- Blinn RL (2012) Arenaeocoris enervates (Hemiptera: Heteroptera: Reduviidae: Stenopodainae), a new genus and species from the Southeastern United States. Zootaxa 3478: 105-110.

- $\quad$ Capriles JM (1995) New Nearctic species of Oncocephalus Klug (Heteroptera: Reduviidae: Stenopodinae). Proceedings of the Washington Entomological Society 97 (4): 791-798.

- $\quad$ Caudell AN (1901) The genus Sinea of Amyot \& Serville. Journal of the New York Entomological Society 9 (1): 1-11.

- Chordas SWI, Kremers J (2008) Two Lygaeoidea (Hemiptera), Ischnodemus slossonae and Cryphula trimaculata, new for Arkansas, U.S.A. Journal of the Arkansas Academy of Science 62: 147-147.

- $\quad$ Chordas SWI, Kremers J (2009) Backyard "bug" collecting results with 6 new state records for Arkansas, U.S.A. Journal of the Arkansas Academy of Science 63: 177-179.

- Chordas SWI, Tumlison R, Robison HW, Kremers J (2011) Twenty three true bug state records for Arkansas, with two for Ohio, U.S.A. Journal of the Arkansas Academy of Science 65: 153-159.

- Chordas SWI, Robison HW, Chapman EG, Crump BG, Kovarik PW (2005) Fifty-four state records of true bugs (Hemiptera: Heteroptera) from Arkansas. Journal of the Arkansas Academy of Science 59: 43-50.

- $\quad$ Crasswell S (2014) True bug glossary. http://www.americaninsects.net/ht/glossary.html. Accession date: 20151203.

- Davidová-Vilímová J, Taylor S, McPherson JE (1996) A new species of Mezira Amyot and Serville (Heteroptera: Aradidae) from Florida, with a key to the small Mezira species of America north of Mexico. Proceedings of the Entomological Society of Washington 98 (4): 630-639.

- $\quad$ Drake CJ, Lattin JD (1963) American species of the lacebug genus Acalypta (Hemiptera: Tingidae). Proceedings of the United States National Museum 115 (3486): 331-345. DOI: 10.5479/si.00963801.115-3486.331

- $\quad$ Froeschner RC (1988a) Aradidae. In: Henry TJ, Froeschner RC (Eds) Catalog of the Heteroptera, or true bugs, of Canada and the continental United States. E.J. Brill, New York, $958 \mathrm{pp}$.

- $\quad$ Froeschner RC (1988b) Cydnidae. In: Henry TJ, Froeschner RC (Eds) Catalog of the Heteroptera, or true bugs, of Canada and the continental United States. E.J. Brill, New York, $958 \mathrm{pp}$.

- Gaspar JP, Minteer CR, McKay T, Raghu S (2015) First records for Pseudomops septentrionalis Hebard (Blattodea: Ectobiidae) and Acantholomidea porosa (Germar) (Heteroptera: Scutelleridae), in Arkansas. Journal of the Kansas Entomological Society 88 (1): 124-127. DOI: 10.2317/JKES1402.28.1

- Hart ER (1986) Genus Zelus Fabricius in the United States, Canada, and Northern Mexico (Hemiptera: Reduviidae). Annals of the Entomological Society of America 79: 535-548. DOI: 10.1093/aesa/79.3.535

- Henry TJ, Froeschner RC (1988) Catalog of the Heteroptera, or true bugs, of Canada and the continental United States. E.J. Brill, New York, 958 pp. 
- $\quad$ Henry TJ, Wheeler AG (1988) Miridae. In: Henry TJ, Froeschner RC (Eds) Catalog of the Heteroptera, or true bugs, of Canada and the continental United States. E.J. Brill, New York, 958 pp.

- Henry TJ, Hevel GF, Chordas SWI (2010) Additional Records of the Little-Known Corixidea major (Heteroptera: Schizopteridae) from Arkansas and Oklahoma. Proceedings of the Entomological Society of Washington 112 (3): 475-477. DOI: 10.428 9/0013-8797-112.3.475

- Kerzhner IM, Henry TJ (2008) Three New Species, Notes and New Records of Poorly Known Species, and an Updated Checklist for the North American Nabidae (Hemiptera: Heteroptera). Proceedings of the Entomological Society of Washington 110 (4):

988-1011. DOI: $10.4289 / 0013-8797-110.4 .988$

- Kittle PD (1980) The water striders (Hemiptera: Gerridae) of Arkansas. Proceedings of the Arkansas Academy of Science 34: 68-71.

- Kormilev NA (1982a) Records and descriptions of North American and Oriental Aradidae (Hemiptera). The Wasmann Journal of Biology 40: 1-17.

- Kormilev NA (1982b) On Mezira granulate (Say) group (Hemiptera: Aradidae). Journal of Natural History 16: 775-779. DOI: 10.1080/00222938200770611

- Lee LA, Barton HE (1983) Distribution and seasonal occurrence of the Scutelleridae, Corimelaenidae and Cydnidae or Arkansas. Arkansas Academy of Science Proceedings 37: 42-46.

- Maw HE, Foottit RG, Hamilton KG, Scudder GG (2000) Checklist of the Hemiptera of Canada and Alaska. NRC Research Press, Ottawa, 220 pp.

- McPherson JE (1982) The Pentatomoidea (Hemiptera) of Northeastern North America with emphasis on the fauna of Illinois. Southern Illinois University Press, Carbondale, 240 pp. [ISBN 0-8093-1040-6]

- O'Donnell JE (2007) A new species of Xestocoris Can Duzee, with comments on the genus (Hemiptera: Heteroptera: Rhyparochromidae: Rhyparochrominae). Zootaxa 1606: 51-57.

- $\quad$ Parshley HM (1921) Essay on the American species of Aradus (Hemiptera). Transactions of the American Entomological Society 47: 1-106.

- Quinn M (2015) Xestocoris. http://bugguide.net/node/view/1124133/bgimage. Accession date: 20151207.

- $\quad$ Schaefer CW (2004) Key to the genera of New World Alydidae (Hemiptera: Heteroptera). Proceedings of the Entomological Society of Washington 106 (2): 280-287.

- $\quad$ Scudder GG (1993) Geographic distribution and biogeography of representative species of xeric grassland-adapted Nearctic Lygaeidae in western North America (Insecta: Heteroptera). Memiors of the Entomological Society of Canada 165: 75-113. DOI: 10.40 39/entm125165075-1

- $\quad$ Scudder GG (2008) New provincial and state records of Heteroptera (Hemiptera) in Canada and United States. Journal of the Entomological Society of British Columbia 105: 3-18.

- $\quad$ Scudder GG (2010) New distribution records for United States Lygaeoidea (Hemiptera: Heteroptera). Journal of the Entomological Society of British Columbia 107: 83-84.

- Sibley LM (1951) A study of reduviids in Louisiana. Proceedings of the Louisiana Academy of Science 14: 88-93. 
- $\quad$ Skvarla MJ, Larson JL, Dowling AP (2014) Pitfalls and preservatives: A review. Journal of the Entomological Society of Ontario 145: 15-43.

- $\quad$ Skvarla MJ, Fisher DM, Schnepp KE, Dowling AP (2015) Terrestrial arthropods of Steel Creek, Buffalo National River, Arkansas. I. Select beetles (Coleoptera: Buprestidae, Carabidae, Cerambycidae, Curculionoidea excluding Scolytinae). Biodiversity Data Journal 3: 1-42. DOI: 10.3897/BDJ.3.e6832

- Skvarla MJ, Smith DR, Fisher DM, Dowling AP (2016) Terrestrial arthropods of Steel Creek, Buffalo National River, Arkansas. II. Sawflies (Insecta: Hymenoptera:

"Symphyta"). Biodiversity Data Journal 4 (8830): 1-17. DOI: 10.3897/BDJ.4.e8830

- Slater JA, Baranowski RM (1978) How to know the true bugs. Wm. C. Brown Company, Dubuque, $256 \mathrm{pp}$.

- $\quad$ Slater JA, Baranowski RM (1990) Lygaeidae of Florida (Hemiptera: Heteroptera). 4. Florida Department of Agriculture and Consumer Services, Gainesville, 211 pp.

- Swanson DR (2011) New state records and distributional notes for some assassin bugs of the continental United States (Heteroptera: Reduviidae). The Great Lakes Entomologist 44: 117-138.

- Taylor SJ, Gill SA (2009) State records, confirmations, and habitats of Aradidae (Hemiptera: Heteroptera) from Louisiana, U.S.A. Florida Entomologist 92 (2): 199-207.

- Taylor SJ, McPherson JE (1989) State records and confirmations of Arkansas flat bugs (Heteroptera: Aradidae). The Great Lakes Entomologist 22 (1): 19-23.

- Usinger RL (1936) Studies in the American Aradidae with descriptions of new species (Hemiptera). Annals of the Entomological Society of America 29: 490-516. DOI: 10.109 3/aesa/29.3.490

- Usinger RL, Matsuda R (1959) Classification of the Aradidae (Hemiptera-Heteroptera). William Clowes and Sons Ltd, London, 410 pp. 